Chapter 5

\title{
Long-Term Crop Rotation, Tillage, and Fertility Effects on Soil Carbon and Nitrogen in Dry-Seeded, Delayed-Flood Rice Production Systems
}

\author{
Jill M. Motschenbacher, Kristofor R. Brye, \\ Merle M. Anders, Edward E. Gbur, \\ Nathan A. Slaton and Michelle A. Evans-White
}

Additional information is available at the end of the chapter

http://dx.doi.org/10.5772/57064

\section{Introduction}

Rice (Oryza sativa L.) production systems occupy 156 million hectares of soil around the world (USDA-FAS, 2012) and rice is considered the world's most important staple food crop due to its prevalence and societal longevity. As a result of human activities, such as cultivation, domestication, dispersal, and diversification, rice is now grown in more than 100 countries across the latitudinal span of $40^{\circ} \mathrm{S}$ to $53^{\circ} \mathrm{N}$ (Chang, 2003), accounting for $20 \%$ of annual worldwide grain production (USDA-FAS, 2012). In the United States, $82 \%$ of the land area used for domestic rice production (1.1 million hectares) occurs in Arkansas (44\%), California $(22 \%)$ and Louisiana (16\%), but smaller quantities of rice are also produced in Texas $(8 \%)$, Mississippi (7\%), and Missouri (6\%; USDA-NASS, 2012). Rice production in the Mississippi Delta region of the United States is primarily drill-seeded during dry conditions as opposed to wet- or transplant-seeded during flooded conditions. These are the two most common methods used in most rice-producing areas of the world (De Datta, 1981).

Drill-seeded rice production systems are unique from other row-crop production systems in that the crop is grown under flood-irrigated conditions from about one month post-emergence until a few weeks prior to harvest, where the upper-most part of the soil profile is nearly to completely saturated (Norman et al., 2003). Drill-seeded rice production systems are also unique from wet- or transplant-seeded rice production systems because they involve shorter periods of saturated soil conditions and longer periods of dry soil conditions as a result of 
delayed flooding and time allowed between cropping periods. Since the cycling of waterlogged and dry soil conditions has been known to greatly influence the storage and cycling of soil organic matter (SOM; IPCC, 2007), drill-seeded rice production systems can play an influential role in the biogeochemical cycling of carbon $(\mathrm{C})$ and nitrogen $(\mathrm{N})$ in agriculturally managed systems.

Soil organic matter is one of the main reservoirs of $C$ in the biosphere (Bernsten et al., 2006). The actual C content in SOM is approximately $57 \%$ by weight (Sundermeiser et al., 2005), with the remaining components made up of oxygen $\left(\mathrm{O}_{2}\right)$, hydrogen, $\mathrm{N}$, and smaller amounts of other nutrients (Bot and Benites, 2005). Follett (2001) estimated that there are about 1550 petagrams $(\mathrm{Pg})$ of soil organic carbon (SOC) stored in the world's soils. This is more than twice the estimated C contained in living vegetation ( $560 \mathrm{Pg}$ ) or in the atmosphere (750 Pg; Sunquist, 1993). Information on the dynamics of SOM and the associated SOC and N storage in agricultural soils has gained interest over recent years because of its influences on global climate change and crop productivity (Majumder et al., 2007; IPCC, 2007).

The concept of global warming is primarily attributed to three $\mathrm{C}$ and $\mathrm{N}$ greenhouse gases that are present both naturally and from anthropogenic sources: carbon dioxide $\left(\mathrm{CO}_{2}\right)$, methane $\left(\mathrm{CH}_{4}\right)$, and nitrous oxide $\left(\mathrm{N}_{2} \mathrm{O}\right.$; IPCC, 2007). According to Lal (2004), land management practices have the potential to enhance SOC accumulation, thereby easing the gaseous $\mathrm{C}$ load to the atmosphere and enriching the soil. The decomposition of SOM, and thus the loss of $\mathrm{C}$ from the soil through the conversion of SOC into the gaseous compounds of $\mathrm{CO}_{2}$ under aerobic conditions and $\mathrm{CH}_{4}$ under anaerobic conditions is promoted by an array of factors, such as location in the soil, fibrous composition of the substrate, nutrient content, soil texture, soil $\mathrm{pH}$, moisture conditions, and soil temperature (Denman et al, 2004; Wolf and Snyder, 2003; Seiter and Horwath, 2004; Alvarez and Lavado, 1998; Bayer, 1996; Filcheva and Mitova, 2002).

The SOM content present in the soil is a reflection of a long-term balance between additions and losses, thus the SOM content is greater when there is a large annual plant productivity rate and a low decomposition rate (Weil and Magdoff, 2004). Therefore, crops that produce large amounts of above-ground biomass have a greater contribution to the overall SOM content. The length of time SOC can be stored in the soil is controlled by the chemical composition of the biomass, which in turn determines the microbial breakdown potential of the substrate (Debusk et al., 2001; Farquhar et al., 2001). In relation to nutrient content, a large portion of the total nitrogen (TN) within soil (90 to 95\%; Smith et al., 1993) occurs along with SOC in the constituents of SOM, and the ratio of $\mathrm{N}$ available in the substrate directly affects the rate of microbial SOM decomposition (McGill and Cole, 1981; Weil and Magdoff, 2004). Thus, the $\mathrm{C}$ and $\mathrm{N}$ cycles are directly linked and the $\mathrm{C}$ cycle of an ecosystem and cannot be properly examined or modeled without giving reference to $\mathrm{N}$ cycling (McGill and Cole, 1981; Weil and Magdoff, 2004). Furthermore, the presence or absence of $\mathrm{O}_{2}$ plays an important role in the process dynamics and management responses of decomposition systems. Generally, an abundant $\mathrm{O}_{2}$ supply promotes rapid decomposition, whereas a deficiency in $\mathrm{O}_{2}$ results in a substantially lower decomposition rate (DeBusk et al., 2001; Shaffer and Ma, 2001). Under 
extremely wet conditions, decomposition can become limited by $\mathrm{O}_{2}$ availability (Wolf and Snyder, 2003). Decreased decomposition rates result in greater accumulations of SOM in saturated soils, which essentially increase the amount of stored SOC and TN within the soil (DeBusk et al., 2001).

Since soil moisture conditions substantially influence the availability of $\mathrm{O}_{2}$, and consequently, the overall storage of SOC and the cycling of $\mathrm{N}$ in the soil, examining crop production systems that contain periods of both aerobic and anaerobic conditions is an important component in accurately estimating the global storage of SOC and TN in agricultural production systems. The most essential aspect of soil management practices is to maintain soil physical properties in a way that supports crop growth and ensures an adequate amount of the biomass gets recycled back to the soil to serve as a long-term organic nutrient source (Lal, 2007). There have been a number of studies examining the changes in SOC due to different production practices, such as crop variety, tillage, fertilization and climate. However, much of the previous research has been conducted in dryland cropping systems across the globe or in paddy-grown rice in Asia. Hence, there is a great deficiency in research pertaining to SOC and TN storage and cycling in other production systems, such as the dry-seeded, delayed-flood rice production system common in the main rice-production region of the United States.

\subsection{Research objectives and hypotheses}

The objective of this study was to evaluate the long-term effects of rice-based crop rotations [i.e., with corn (Zea mays L.), soybean (Glycine max L.), and winter wheat (Triticum aestivum L.)], tillage [conventional tillage (CT) and no-tillage (NT)], and soil fertility (optimal and suboptimal) on SOC and TN contents, the partitioning of SOC and TN in SOM, and C:N soil ratios in the top $10 \mathrm{~cm}$ of a silt-loam soil after 11 years (1999 to 2010) of consistent management. Furthermore, SOC and TN contents were modeled for the 11-year period and into the future using the Century soil organic model (Parton et al., 1987; NREL, 2006). It was hypothesized that: (1) NT practices would have greater SOC and TN than that under CT over time as a result of decreased aeration and soil disturbance; (2) rotations with increased frequencies of highresidue-producing crops, such as rice, corn, and those double-cropped with wheat, would have greater SOC and TN from greater amounts of biomass returned to the soil than lower-residue producing crop rotations, such as those with greater frequencies of soybean; (3) the optimal fertility regime would have greater SOC and TN than that in the sub-optimal fertility regime over time as a result of increased biomass production related with greater nutrient inputs from fertilizer; (4) the partitioning of SOC and TN in SOM would not vary greatly as a result of treatment combinations; (5) soil C:N ratios would be greater in high-residue-producing rotations, such as rice and corn, and would be lower in rotations including soybean, as a result of crop residue inputs; and (6) the Century model outcomes are expected to be correlated with measured SOC and TN obtained in the study. The Century model is expected to show that systems with high-residue-producing crops, NT, and optimal fertility result in greater SOM in the soil, thus increasing the SOC and TN contents over time more in these treatment combinations than in others. 


\section{Materials and methods}

\subsection{Site description}

This field study was conducted at the University of Arkansas' Rice Research and Extension Center (RREC) near Stuttgart $\left(34^{\circ} 27^{\prime} \mathrm{N}, 9^{\circ} 24^{\prime} \mathrm{W}\right)$, which is located in the Mississippi Delta region of eastern Arkansas in an area known as the Grand Prairie (USACE, 2000). The geographic area is made up of silt-loam and clay-textured soils from the Southern Mississippi River Alluvium and terraces and the Arkansas River Alluvium, which are Major Land Resource Areas 131A and 131B, respectively (USDA-NRCS, 2008). The 30-yr mean monthly air temperature ranges from a minimum of $0.2^{\circ} \mathrm{C}$ in January to a maximum of $33.1^{\circ} \mathrm{C}$ in July, and the 30-yr mean annual precipitation is $132 \mathrm{~cm}$ (SRCC, 2012).

The study began in 1999 on a Dewitt silt loam (fine, smectitic, thermic, Typic Albaqualf; USDANRCS, 2008), which is a common soil present in the Grand Prairie region. The Dewitt series is made up of very deep, poorly drained, slowly permeable soils that formed in alluvium (USDANRCS, 2008). The top $10 \mathrm{~cm}$ are primarily dark grayish brown (10YR 4/2) in color when the soil is moist and have a moderate medium granular structure near the surface and weak medium and course subangular blocky structure in the sub-soil (USDA-NRCS, 2008).

Prior to the initiation of the study in 1999, the study area had been fallow for numerous years due to a lack of irrigation capability. Vegetation present consisted of a mixture of grasses and weeds that were mowed in the summer. In preparation for the study, the site was land leveled to a $0.15 \%$ grade in Fall 1998, which is common practice in the area to facilitate uniform distribution of flood-irrigation water (Brye et al., 2003). Top soil was first removed, piled off to the side of the area, and then spread back over the area that was leveled.

\subsection{Experimental design and field treatments}

The experimental design for this study was a randomized complete block, with each block partitioned as a split-strip-split plot. The blocks included four rectangular sections 76-m long by 120 -m wide $\left(9120 \mathrm{~m}^{2}\right)$ within the 1.9-ha experimental site. Each block was divided into two tillage treatments (CT and NT) and each tillage treatment was split into two fertility regimes (optimal and sub-optimal). Each of the tillage-fertility combinations were stripped across with six crop rotations and split across time (1999 and 2010). The six crop rotations included continuous rice $(R)$, rice-soybean (RS), rice-corn $(R C)$, rice (winter wheat) $[R(W)]$, rice (winter wheat)-soybean (winter wheat) $[R(W) S(W)]$, and rice-corn-soybean (RCS). All rotations evaluated started with rice during the first year of the study and followed the respective rotations in successive years (Table 1). There were 96 plots evaluated and each plot representing a tillage-fertility-rotation treatment combination measured 6- by $19-\mathrm{m}$.

In the CT treatment, crop residues were incorporated into the soil by disking one to two months following harvest and prior to spring planting. Spring field preparation was also followed by multiple passes with a light field cultivator (i.e., Triple-K) to achieve the desired seedbed for rice planting. In the NT treatment, crop residues were left on the surface after harvest and were 


\begin{tabular}{|c|c|c|c|c|c|c|}
\hline \multirow[b]{2}{*}{ Year } & \multicolumn{6}{|c|}{ Rotation } \\
\hline & $\mathbf{R}$ & RS & $\mathrm{RC}$ & $R(W)$ & $R(W) S(W)$ & RCS \\
\hline 1999 & Rice & Rice & Rice & Rice & Rice & Rice \\
\hline 2000 & Rice & Soybean & Corn & Rice & Soybean & Corn \\
\hline 2001 & Rice & Rice & Rice & Rice & Rice & Soybean \\
\hline 2002 & Rice & Soybean & Corn & Rice & Soybean & Rice \\
\hline 2003 & Rice & Rice & Rice & Rice & Rice & Corn \\
\hline 2004 & Rice & Soybean & Corn & Rice & Soybean & Soybean \\
\hline 2005 & Rice & Rice & Rice & Rice & Rice & Rice \\
\hline 2006 & Rice & Soybean & Corn & Rice & Soybean & Corn \\
\hline 2007 & Rice & Rice & Rice & Rice & Rice & Soybean \\
\hline 2008 & Rice & Soybean & Corn & Rice & Soybean & Rice \\
\hline 2009 & Rice & Rice & Rice & Rice & Rice & Corn \\
\hline 2010 & Rice & Soybean & Corn & Rice & Soybean & Soybean \\
\hline
\end{tabular}

Table 1. Summary of summer crop rotations by year with all rotations tilled prior to planting in 1999 and the notillage treatment starting in 2000 . Crops used in the rotations include rice (R), soybean (S), corn (C), and winter wheat $[(\mathrm{W})]$. Crops in parentheses were grown in the winter.

not manipulated by any means prior to planting in the spring. Rice, soybean, and wheat were sown into 19-cm rows in both tillage treatments using an Almaco NT drill (Almaco, Nevada, IA). Rice was drill-seeded at a rate of $100 \mathrm{~kg}$ seed ha- ${ }^{-1}$, soybean at a rate of $56 \mathrm{~kg}$ seed ha-1, and wheat at a rate of $67 \mathrm{~kg}$ seed ha-1. Corn was planted in $76-\mathrm{cm}$ rows at a plant population of 79,000 seeds ha-1. Fertility treatments applied were based on soil analyses from the study site at the beginning of the study in 1999 (Table 2). Each year, phosphorus (P) was applied as triple super phosphate and potassium $(\mathrm{K})$ was applied as muriate of potash, which were broadcast pre-plant and pre-tillage with a hand-spreader. During the years rice was grown, zinc (Zn) was applied as zinc sulfate, which was also broadcast pre-plant and pre-tillage with a handspreader. Nitrogen was applied as urea with a hand-spreader pre-flood approximately one month after planting. Phosphorous, $\mathrm{K}$, and $\mathrm{Zn}$ were incorporated into the soil in the CT treatment and were applied to the surface in the NT treatment.

Following $\mathrm{N}$ fertilization of the rice, a 5- to 10 -cm permanent flood was established, which was maintained on all of the rice plots throughout the growth period. Corn and soybean were furrow-irrigated on an as-needed basis during the summer growth period, with the irrigation amount varying based on the rainfall received and the growth of the crop. Irrigation water originated from a nearby surface reservoir, with water additions mainly from an adjacent stream channel and some groundwater. Wheat grown during the winter was rainfed only. All recommendations for stand establishment, irrigation, weed control and pest management for rice (Slaton, 2001), soybean (Ashlock, 2000), corn (Espinoza and Ross, 2003) and wheat (Kelley, 


\begin{tabular}{cccc}
\hline & & \multicolumn{2}{c}{ Soil Fertility Treatment $^{\left(\mathbf{k g ~ h a}^{-1} \mathbf{)}\right.}$} \\
\hline Crop & Nutrient & Sub-Optimal & Optimal \\
\hline Corn & $\mathrm{N}$ & 224 & 337 \\
& $\mathrm{P}_{2} \mathrm{O}_{5}$ & 67 & 90 \\
Soybean & $\mathrm{K}_{2} \mathrm{O}$ & 112 & 168 \\
& $\mathrm{~N}$ & 0 & 0 \\
& $\mathrm{P}_{2} \mathrm{O}_{5}$ & 45 & 67 \\
Rice & $\mathrm{K}_{2} \mathrm{O}$ & 67 & 135 \\
& $\mathrm{~N}$ & 112 & 168 \\
& $\mathrm{P}_{2} \mathrm{O}_{5}$ & 45 & 67 \\
& $\mathrm{~K}_{2} \mathrm{O}$ & 67 & 101 \\
& $\mathrm{ZnSO}_{4}$ & 11 & 11 \\
& $\mathrm{~N}$ & 112 & 168 \\
& $\mathrm{P}_{2} \mathrm{O}_{5}$ & 34 & 67 \\
& $\mathrm{~K}_{2} \mathrm{O}$ & 34 & 67 \\
\hline
\end{tabular}

Table 2. Summary of the annual nitrogen $(N)$, phosphorous $(P)$, potassium (K), and zinc (Zn) added to corn, soybean, rice and winter wheat to comprise the optimal soil fertility treatments in a long-term, rice-based rotation study at the Rice Research and Extension Center near Stuttgart, AR on a silt-loam soil.

1999) followed the University of Arkansas Cooperative Extension Service recommendations for the duration of the study.

\subsection{Soil sampling and analyses}

Soil samples were collected from the top $10 \mathrm{~cm}$ in each tillage-fertility-rotation treatment combination prior to spring planting in March during both evaluation years. The 1999 samples were collected after land leveling had occurred and prior to any actual field treatment. The 2010 samples were collected prior to the spring planting of rice, corn or soybean. During the time of sampling in 2010, wheat was present in the $R(W)$ and $R(W) S(W)$ rotations, whereas the $\mathrm{R}, \mathrm{RS}, \mathrm{RC}$, and RCS rotations were still fallow from the winter. Soil samples for both years were dried at $70^{\circ} \mathrm{C}$ in a forced-draft oven for 48 hours. In 2010, soil samples were acquired using a 4.7-cm diameter stainless steel cylinder. Following drying, samples were weighed for bulk density determination. In 1999, bulk density was not measured; therefore, soil particle-size analyses were conducted on all of the 2010 soil samples from the top $10 \mathrm{~cm}$ in order to estimate bulk density. The percentages of sand and clay measured from the 2010 samples were combined with measured SOM concentrations from 1999 to estimate bulk density for the 1999 samples on a plot-by-plot basis, using the bulk density prediction equation incorporated in the Soil-Plant-Atmosphere-Water (SPAW) model (Saxton and Rawls, 2006).

In both 1999 and 2010, total C and TN were measured by high-temperature combustion after samples were crushed to pass a 2-mm mesh screen. All measured C was assumed to be associated with the organic fraction of the soil because, upon treatment with concentrated hydrochloric acid $(\mathrm{HCl})$, there was no effervescence. Therefore, all measured $\mathrm{C}$ is hereafter 
referred to as SOC. Measured SOC and TN concentrations $\left(\mathrm{mg} \mathrm{kg}^{-1}\right)$ were converted to contents $\left(\mathrm{kg} \mathrm{m}^{-2}\right)$ using the 10-cm sampling depth and soil bulk densities. The partitioning of SOC and TN within SOM, in addition to C:N ratios, were calculated from SOM, SOC, and TN concentrations measured in each tillage-fertility-rotation treatment combination.

When the 2010 samples were collected after 11 years of management, $R$ and $R(W)$ rotations had produced 11 rice crops, and the $\mathrm{RS}, \mathrm{RC}$, and $\mathrm{R}(\mathrm{W}) \mathrm{S}(\mathrm{W})$ rotations had produced six rice crops with five crops in the respective rotation with corn or soybean (Table 3). Furthermore, the RCS rotation had produced four rice crops, four corn crops, and three soybean crops, and the $R(W)$ and $R(W) S(W)$ rotations with had produced 11 winter wheat crops (Table 3). Tillage had occurred in the tilled plots five months before (late-October 2009) the collection of samples in March 2010.

\begin{tabular}{lcccc}
\hline & Rotation & \multicolumn{4}{c}{ Number of Crops } \\
\cline { 2 - 5 } & Rice & Corn & Soybean & Wheat \\
\hline Continuous Rice & 11 & - & - & - \\
Rice-Soybean & 6 & - & 5 & - \\
Rice-Corn & 6 & 5 & - & - \\
Rice-(Wheat) & 11 & - & - & 11 \\
Rice-(Wheat)-Soybean-(Wheat) & 6 & - & 5 & 11 \\
Rice-Corn-Soybean & 4 & 4 & 3 & - \\
\hline
\end{tabular}

Table 3. Summary of the crop rotations and the number of crops grown in the respective rotations during the 11-yr study period (1999 to 2010) at the Rice Research and Extension Center near Stuttgart, AR on a silt-loam soil. Crops in parentheses were grown during the winter.

\subsection{Century model simulation}

For comparison to measured data over time, simulations using the Century model were conducted for each tillage-fertility-rotation treatment combination. Century is a SOM model that simulates $\mathrm{C}$ and $\mathrm{N}$ cycling in different plant production systems based on a monthly time step (Parton et al., 1987, 1988; Parton and Rasmussen, 1994). The model works by allocating various plant components and animal excreta into different SOM pools with varying timescales of decomposition, which include the active (a few months to a few years), slow (20 to 50 years), or passive (400 to 2000 years) pools. This is done by partitioning plant residues as either structural or metabolic organic pools based on their lignin:N ratio (Shibu et al., 2006), in that plant parts with a larger ratio take longer to decompose. The model works by dividing the structural pool into lignin and cellulose components (NREL, 2006). The lignin is moved to the slow decomposition pool, whereas the cellulose and metabolic C (i.e., microbial biomass) are added to the active pool. The actual decomposition rates of the SOM from the active pool are calculated based on soil texture, soil temperature and soil moisture and the decomposition rates of the structural pool are determined based upon the lignin content of the plant material. 
In the Century model, the nitrification process is not incorporated because there is no distinction made within the mineral-N pool between nitrate and ammonium (Shibu et al., 2006).

The limitations of the model in relation to rice-based cropping systems are that it was originally designed for grasslands, arable lands, forests and savanna ecosystems under aerobic conditions (NREL, 2006; Parton et al., 1988), not periodically flooded ecosystems. This has resulted in the Century model not being extensively used to simulate rice-based crop rotations. However, Bhattacharyya et al. (2007) used Century to model a jute (Cochorus capsularis L.)-ricewheat rotation in West Bengal, India and Milne et al. (2008) modeled a 3-year rice-soybean, wheat-soybean rotation in eastern Arkansas, United States, in which the field was flooded for rice production once every three years. Bharracharyya et al. (2007) reported that the model overestimated SOC content, but was able to simulate trends in SOC cycling over the 30-year study period. Milne et al. (2008) reported that the model underestimated the increase of SOC content in the first year, but concluded that Century could be used to accurately predict the long-term SOC dynamics in rice-based crop rotations that are flooded every three years.

Parameters for the Century SOM model (Parton et al., 1987; NREL, 2006) simulation in this study were adjusted using a combination of recorded historic climatic data, measured plant properties and responses, and measured soil data for the top $10 \mathrm{~cm}$ that were adjusted to reflect a depth of $20 \mathrm{~cm}$. In 1999, soil samples had only been collected from the top $10 \mathrm{~cm}$, whereas 2010 samples were collected from both the 0 - to 10 - and 10- to 20-cm depths. In order to model trends over time using Century, which only simulates $\mathrm{C}$ and $\mathrm{N}$ cycling in a fixed depth of the top $20 \mathrm{~cm}$, depth adjustments had to be made from the measured 0- to 10-cm sampling depth to reflect the top $20 \mathrm{~cm}$. In order to calculate the percentage of SOC and TN that was contained in the top $10 \mathrm{~cm}$ of the 0 - to $20-\mathrm{cm}$ depth interval, the average percent content was calculated from the 2010 soil samples. Based on 192 samples from both the top $10 \mathrm{~cm}$ and the 10- to 20$\mathrm{cm}$ depth, the top $10 \mathrm{~cm}$ contained an average of $66 \%$ of the SOC and $61 \%$ of the TN in the top $20 \mathrm{~cm}$ of soil. To facilitate comparison to measured data from the top $10 \mathrm{~cm}$, output values from Century from the top $20 \mathrm{~cm}$ were adjusted to SOC and TN contents for the top $10 \mathrm{~cm}$ based on the average calculated percentages from observed data.

Different simulated model designs for field treatments were set up for each tillage-fertilityrotation treatment combination. However, the input file for all model designs used the same values for monthly average maximum and minimum air temperature (SRCC, 2012), monthly precipitation (SRCC, 2012), soil texture, soil bulk density, soil pH, and initial SOC and TN contents from 1999. This approach was justified because the entire study site was uniformly maintained and land leveled prior to the initiation of the study and SOC and TN concentrations were similar across the study site in 1999. Therefore, all model input files started with the same site and control parameters for the model. The initial values for soil texture, soil bulk density, and SOC and TN contents were fixed based on the average values across all preassigned tillagefertility-rotation treatment combinations. Any observed differences among tillage-fertilityrotation treatment combinations over time were assumed to be a result of the imposed treatments instead of inherent differences in soil physical and chemical properties. Anaerobic conditions associated with flooding during the rice growing season, which results in slower 
decomposition rates, were accounted for by adjusting the drainage potential of the soil and the irrigation frequency.

\subsection{Data analyses}

Initial soil properties in 1999, in addition to the effects of tillage, fertility regime, crop rotation, over time (1999-2010) on SOC and TN contents, the partitioning of SOC and TN in SOM, and C:N ratios were evaluated by analysis of variance (ANOVA) using the PROC MIXED procedure in SAS $^{\circledR}$ (version 9.2, SAS Institute, Inc., Cary, NC). When appropriate, means were separated using Fisher's protected least significant difference (LSD) at the 0.05 level. Modeled results for SOC and TN storage trends over time were compared to direct observations via a linear regression analyses using Minitab (version 15, Minitab, Inc., State College, PA).

\section{Results and discussion}

\subsection{Initial soil properties}

Samples collected at the initiation of the study in 1999, which were collected after land leveling and prior to the implementation of tillage, fertility, and rotation treatments, showed that soil properties in the top $10 \mathrm{~cm}$ were primarily uniform among preassigned tillage-fertility-rotation treatment combinations. There were no differences in SOC and TN contents, the partitioning of SOC and TN within SOM, and soil C:N ratios among preassigned tillage, fertility, and/or rotation treatments $(P>0.05$; Table 4$)$. Furthermore, the soil particle-size distribution did not differ among any treatment combinations when measured in $2010(P>0.05$; Table 4$)$.

\begin{tabular}{cccccccc}
\hline Treatment Effect & BD & SOC & TN & SOC/SOM & TN/SOM & C:N \\
\hline & & & & & & & \\
\hline Tillage & 0.595 & 0.345 & 0.139 & 0.382 & 0.683 & 0.452 \\
Fertility & 0.569 & 0.550 & 0.396 & 0.392 & 0.588 & 0.531 \\
Fertility* Tillage & 0.517 & 0.544 & 0.523 & 0.451 & 0.484 & 0.553 \\
Rotation & $\mathbf{0 . 0 0 5}$ & 0.113 & 0.671 & 0.320 & 0.921 & 0.349 \\
Rotation*Tillage & 0.316 & 0.999 & 1.000 & 0.873 & 0.811 & 0.993 \\
Rotation*Fertility & 0.418 & 0.400 & 0.397 & 0.488 & 0.762 & 0.760 \\
Rotation*Tillage*Fertility & 0.313 & 0.253 & 0.305 & 0.515 & 0.189 & 0.772 \\
\hline
\end{tabular}

Table 4. Analysis of variance summary of the inherent differences of soil properties before tillage, fertility and crop rotation treatments. Soil properties and their interactions related to the inherent soil differences in the assigned treatment combinations on soil bulk density (BD), soil organic carbon (SOC) content, total nitrogen (TN) content, portion of SOC in soil organic matter (SOM), portion of TN in SOM, and carbon to nitrogen ratios (C:N) prior to any treatment being imposed in 1999. The study site was located at the Rice Research and Extension Center near Stuttgart, AR on a silt-loam soil. Treatment effects in bold are considered non-significant $(P>0.05)$.

Although there were no SOC and TN related soil property differences among preassigned treatments in 1999, there were a few minor inherent differences in estimated soil bulk density 
$(P=0.005)$ among preassigned rotations (Table 4$)$. Estimated soil bulk density in the $\mathrm{R}(\mathrm{W})(1.44$ $\left.\mathrm{g} \mathrm{cm}^{-3}\right)$ rotation was 2 to $4 \%$ greater than that in the $\mathrm{R}\left(1.41 \mathrm{~g} \mathrm{~cm}^{-3}\right), \mathrm{RC}\left(1.40 \mathrm{~g} \mathrm{~cm}^{-3}\right)$, and RCS $\left(1.38 \mathrm{~g} \mathrm{~cm}^{-3}\right)$ rotations, when averaged across preassigned tillage and fertility treatments. Furthermore, estimated soil bulk density was 3\% greater in the R(W)S(W) and RS (both $1.42 \mathrm{~g}$ $\mathrm{cm}^{-3}$ ) rotations than in the RCS rotation. Though statistically different, all differences in soil bulk density were $\leq 0.06 \mathrm{~g} \mathrm{~cm}^{-3}$, which are not large enough to cause substantial differences in SOC and TN contents.

\subsection{Tillage effects on $\mathrm{SOC}$ and $\mathrm{TN}$}

Similar to that hypothesized, when averaged across fertility regimes, crop rotations and time, SOC content $\left(\mathrm{kg} \mathrm{m}^{-2}\right)$ in the top $10 \mathrm{~cm}$ was affected by tillage $(P=0.012)$, and when averaged across fertility regimes and crop rotations, TN content $\left(\mathrm{kg} \mathrm{N} \mathrm{m}^{-2}\right)$ differed over time between tillage treatments $(P=0.019$; Table 5). Soil organic carbon content was $14 \%$ greater under NT $\left(1.14 \mathrm{~kg} \mathrm{~m}^{-2}\right)$ than under CT (1.00 $\mathrm{kg} \mathrm{m}^{-2}$; Figure 1$)$, but unlike what was expected, SOC content did not differ between the tillage treatments over time (i.e., 1999 to 2010; $P=0.075$ ). However, as expected, TN content increased 34\% from $1999\left(0.10 \mathrm{~kg} \mathrm{~m}^{-2}\right)$ to $2010\left(0.13 \mathrm{~kg} \mathrm{~m}^{-2}\right)$ under NT, but did not differ over time under CT (Figure 2). Consequently, NT management resulted in a net TN sequestration rate of about $0.003 \mathrm{~kg} \mathrm{~m}^{-2} \mathrm{yr}^{-1}$ from 1999 to 2010.

\begin{tabular}{cccccc}
\hline Treatment Effect & SOC & TN & SOC/SOM & TN/SOM & C:N \\
\hline & & & & & \\
\hline Tillage & & & & \\
Fertility & $\mathbf{0 . 0 1 2}$ & $\mathbf{0 . 0 0 2}$ & $\mathbf{0 . 0 0 7}$ & 0.169 & 0.861 \\
Fertility* Tillage & 0.469 & 0.080 & 0.589 & 0.167 & 0.349 \\
Rotation & 0.538 & 0.678 & 0.319 & 0.322 & 0.377 \\
Rotation*Tillage & 0.120 & $\mathbf{0 . 0 1 0}$ & 0.941 & 0.591 & 0.231 \\
Rotation*Fertility & 0.543 & 0.548 & 0.495 & 0.635 & 0.964 \\
Rotation*Tillage*Fertility & 0.535 & 0.364 & 0.517 & 0.352 & 0.670 \\
Time & 0.839 & 0.441 & 0.464 & 0.457 & 0.447 \\
Time*Tillage & $\mathbf{0 . 0 3 9}$ & $\mathbf{0 . 0 3 6}$ & 0.837 & 0.214 & 0.155 \\
Time*Fertility & 0.075 & $\mathbf{0 . 0 1 9}$ & 0.595 & 0.098 & 0.193 \\
Time*Rotation & 0.466 & 0.064 & 0.526 & 0.099 & 0.179 \\
Time*Tillage*Fertility & $<\mathbf{0 . 0 0 1}$ & $\mathbf{0 . 0 0 3}$ & $\mathbf{0 . 0 4 7}$ & $\mathbf{0 . 0 3 7}$ & 0.654 \\
Time*Tillage*Rotation & 0.623 & 0.738 & 0.348 & 0.344 & 0.580 \\
Time*Fertility*Rotation & 0.275 & 0.820 & 0.533 & 0.871 & 0.643 \\
Time*Tillage*Fertility*Rotation & 0.505 & 0.302 & 0.464 & 0.235 & 0.898
\end{tabular}

Table 5. Analysis of variance summary of the effects of tillage, fertility, crop rotation and time on soil organic carbon (SOC) and total nitrogen (TN) contents, SOC and TN fractions of the soil organic matter (SOM), and carbon to nitrogen ratios (C:N) after 11 years of consistent management. 


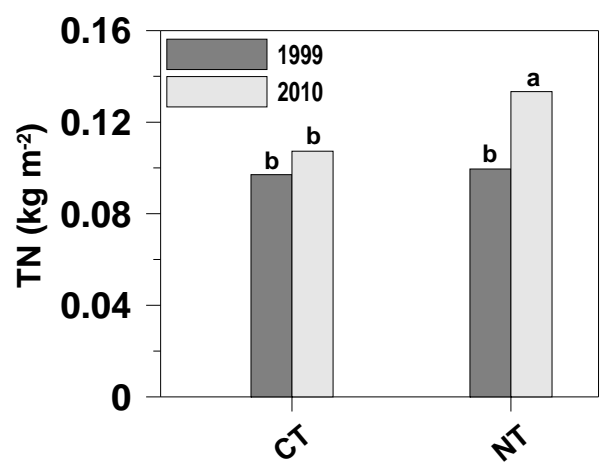

Tillage Treatment

Figure 1. Tillage [conventional tillage (CT) and no-tillage (NT)] and time (1999 and 2010) effects on total nitrogen (TN) in the top $10 \mathrm{~cm}$. Different letters atop bars are significantly different at the 0.05 level.
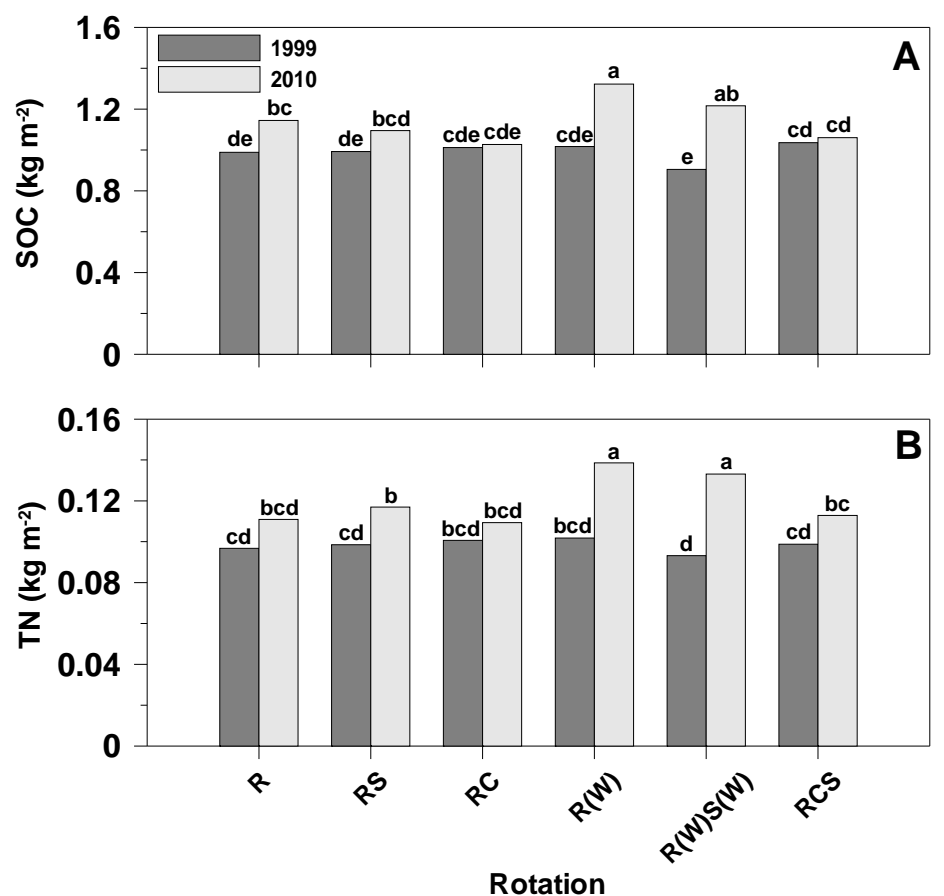

Figure 2. Rotation [rice (R), soybean (S), corn (C) and winter wheat (W)] and time (1999 and 2010) effects on soil organic carbon (SOC) $[A]$ and total nitrogen $(T N)[B]$ in the top $10 \mathrm{~cm}$. Different letters atop bars within a panel are significantly different at the 0.05 level. 
Tillage effects on SOC and TN contents appear to be directly related to SOM content differences, whereas the SOM content was $9 \%$ greater under NT $\left(2.88 \mathrm{~kg} \mathrm{~m}^{-2}\right)$ than under CT $(2.64$ $\mathrm{kg} \mathrm{m}^{-2}$ ), when averaged across all other treatments (Motschenbacher et al., 2012). Although SOC content did not differ over time, the increase in TN content over time under NT corresponded to the $14 \%$ increase in SOM content over the same time period [1999 $\left(2.58 \mathrm{~kg} \mathrm{~m}^{-2}\right)$ to 2010 (2.95 kg m²); Motschenbacher et al., 2012], when averaged across all other treatments. Similar to results observed in this study, greater SOC under NT as opposed to that under CT is a common occurrence, widely reported in past agronomic studies (West and Post, 2002; McCarty et al., 1998; Xu et al., 2007). Soils that have been degraded through excessive tillage tend to have less SOM due to an increased amount of exposed surface area, which facilitates aerobic decomposition (DeBusk et al., 2001). Carbon makes up more than half the mass of SOM (Montgomery et al., 2000), and it has been shown that cultivating the land influences the dynamics of SOC and, in turn, the amount of $\mathrm{C}$ emitted from the soil as $\mathrm{CO}_{2}$ due to the oxidation or decomposition of SOM (Paustian et al, 1995; Reicosky et al., 1995).

Although flooded-soil conditions in rice-based crop rotations alter the environmental conditions contributing to $\mathrm{C}$ and $\mathrm{N}$ sequestration and cycling, due to slower decomposition rates and increased $\mathrm{CH}_{4}$ emissions as opposed to $\mathrm{CO}_{2}$ emissions, studies of long-term effects of different tillage regimes implemented in non-flooded upland soils can also provide insight on the impacts of soil disturbance from tillage. Salinas-Garcia et al. (1997) reported that a decrease in tillage increased SOM, microbial biomass $\mathrm{C}$, inorganic $\mathrm{N}$, and labile $\mathrm{C}$ and $\mathrm{N}$ pools compared to tilled systems in a long-term quadrennial corn-cotton (Gossypium hirsutum) rotation on a sandy-clay-loam soil in Texas. Furthermore, West and Post (2002) showed that among 67 nonflooded, long-term studies of various soil textures in countries throughout the world, the average soil C sequestration rate was $57 \pm 14 \mathrm{~g} \mathrm{C} \mathrm{m}^{-2} \mathrm{yr}^{-1}$ on land converted from CT to NT systems, with the exclusion of wheat-fallow systems. West and Post (2002) also estimated that $\mathrm{C}$ sequestration reaches a maximum between 5 and 10 years after conversion from CT to NT, and after 15 to 20 years the soil reaches a greater equilibrium $C$ concentration.

In a study evaluating a wheat-soybean double-cropping system on a silt-loam soil in eastcentral eastern Arkansas, SOC content was greater under NT in the top $10 \mathrm{~cm}$ than that under $\mathrm{CT}$ after two years of continuous cultivation (Brye et al., 2006a) and $\mathrm{C}$ lost as $\mathrm{CO}_{2}$ from soil respiration was 38\% greater from CT than from NT (Brye et al., 2006b). Reicosky and Lindstrom (1993) attributed the large initial rate of soil surface $\mathrm{CO}_{2}$ flux after tillage to the release of $\mathrm{CO}_{2}$ in newly exposed soil pores and from dissolution or direct oxidation of $\mathrm{C}$ substrates, which further demonstrates the loss of $\mathrm{C}$ through increased decomposition rates as a result of aeration from tillage. Furthermore, SOM is made up of approximately $5 \% \mathrm{~N}$, which is mineralized into ammonium $\left(\mathrm{NH}_{4}^{+}\right)$during the decomposition process. Mineralized $\mathrm{N}$ is susceptible to removal from or translocation within the soil after nitrification through the leaching of nitrate $\left(\mathrm{NO}_{3}{ }^{-}\right)$ and through gaseous losses during denitrification (Havlin et al., 2005; Schlesinger, 1997).

The reduction of tillage intensity by switching from CT to NT has been widely recognized as management practice that increases the amount of C storage in soils (Lal and Kimble, 1997; Doa, 1998; Kern and Johnson, 1993; Dick et al.,1998) and influences N cycling (Shaffer and Ma, 2001) in the near-surface soil. McCarty et al. (1998) reported increased SOC (38\%), microbial 
biomass C (33\%), TN (30\%), and microbial biomass N (87\%) concentrations in the top $2.5 \mathrm{~cm}$ of a silt-loam soil three years after the transition from CT to NT on a continuous corn rotation in the United States, whereas SOC (7\%), microbial biomass C (15\%), TN (6\%), and microbial biomass $\mathrm{N}$ (35\%) concentrations in the 12.5 to $20 \mathrm{~cm}$ depth decreased. An 18-year study of a rice-wheat rotation on a clay-loam soil in China also showed greater $\mathrm{SOC}, \mathrm{TN}$, and microbial biomass $\mathrm{C}$ and $\mathrm{N}$ concentrations in the top $5 \mathrm{~cm}$ under NT compared with $\mathrm{CT}$, whereas SOC and TN concentrations were greater in the $5-$ to $10-\mathrm{cm}$ and $10-$ to $20-\mathrm{cm}$ depths under CT compared with NT (Xu et al., 2007). The results of previous studies suggest the elimination of tillage greatly influences the stratification of SOC and TN in the near-surface soil layers, whereas there are greater quantities of less-decomposed residue in the upper-most soil layers under NT and that the SOC and TN contents decrease with depth.

In contrast, SOC and TN contents are commonly unstratified and similar throughout the plow layer under CT because the mechanical mixing action of tillage distributes residue more evenly. Tillage also allows for the incorporation of SOM deeper into the soil by mixing plant residue and microbial biomass that usually remains in the upper-most layers under undisturbed conditions. This mixing action in the plow layer can result in greater SOC and TN contents in soil depths immediately below the plow depth under CT than that under NT due to the placement of the SOM near the bottom of the plow layer under full-inversion tillage (Angers and Eriksen-Hamel, 2008).

\subsection{Fertility regime effects on SOC and TN}

In contrast to that hypothesized, SOC and TN contents in the top $10 \mathrm{~cm}$ did not differ between fertility regimes imposed in the study $(P>0.05$; Table 5$)$. Fertilization of the soil has been well documented as being directly correlated to the quantity of biomass produced, which in turn is directly correlated with the amount of crop residues that are returned to the soil to become SOM, thus contributing to the SOC and TN pools (Follett, 2001). However, in this study the differences among optimal and sub-optimal fertility treatments (Table 2) were likely not great enough to significantly affect SOC and TN contents even after 11 years of consistent management. The lack of fertility treatment differences in SOC and TN contents between optimal and sub-optimal fertility directly correspond to the lack of differences in SOM contents that were also observed in this study, when averaged across all other treatment factors $(P>0.05$; Motschenbacher et al., 2012). However, the lack of SOC and TN content differences under optimal and sub-optimal fertility do not mean that soil fertilizer treatments failed to increase the overall input of crop residues added to the soil when compared to the quantity that would be added upon the elimination of N-P-K treatments. For the purposes of this, only the effects of commonly recommended fertilizer rates provided to producers in the Mississippi Delta area of eastern Arkansas were evaluated (Table 2; Espinoza et al., 2007). Therefore, the design of this study did not include a control treatment in which no fertilizer was applied, as that would not be a common recommendation for field-crop production in the geographic study area.

Furthermore, there is a chance that differences in the fertility treatments over time might have existed if soil of a greater depth interval was compared. Electrical conductivity (EC) values evaluated in Motschenbacher et al. (2012) decreased substantially over the 11-year time period 
evaluated, which suggests that nutrient leaching beyond the top $10 \mathrm{~cm}$ occurred from the infiltration and movement of irrigation water. Therefore, it is reasonable to assume that some of the SOC and TN could have also leached further into the profile with the irrigation water. Therefore, differences between fertilizer treatments might have been too small to be significant in analyses from the top $10 \mathrm{~cm}$, but lower soil depths could potentially show differences related to imposed fertility regimes.

Based on past studies, it can be assumed that both fertilization treatments allowed a greater quantity of above-ground biomass to be returned to the soil than would have been returned without fertilization. Halvorson et al. (2002) reported that $\mathrm{N}$ fertilization increased the quantity of crop residue returned to the soil in the top $30 \mathrm{~cm}$ of a loam soil after 12 years in two dryland cropping systems in North Dakota. The dryland cropping systems used in the study included spring wheat-winter wheat-sunflower (Helianthus annuus L.) and spring wheat-fallow rotations under different tillage treatments (Halvorson et al., 2002). Clapp et al. (2000) had similar findings in a 13-year study in the 15- to 30-cm depth of a silt-loam soil in Minnesota, which showed that adding $\mathrm{N}$ fertilizer to a corn cropping system increased SOC content when residues were returned to the soil in NT systems. On average, soil fertility management practices are estimated to add roughly 50 to $150 \mathrm{~kg} \mathrm{ha}^{-1}$ of SOC to the soil every year, depending on the cropping system (Lal et al., 1998).

In the United States, most of the rice cultivars grown require 135 to $200 \mathrm{~kg} \mathrm{ha}^{-1}$ of $\mathrm{N}$ fertilizer to produce profitable grain yields (Norman et al., 2003). Shen et al. (2007) indicated that chemical fertilizer treatments produced a net gain of 16 to $18 \mathrm{~g} \mathrm{SOC} \mathrm{kg} \mathrm{soil-1}^{-1}$ in rice-wheat agroecosystems in China when compared to untreated rice-wheat agroecosystems. In an 18year study of a rice-wheat rotation in China, Xu et al. (2007) reported greater SOC and TN concentration increases in the top $10 \mathrm{~cm}$ when a combination of organic and inorganic N-P-K fertilization treatments were applied to a clay-loam soil than with no fertilization. Furthermore, Pampolino et al. (2008) reported that cropping systems delivering two to three rice crops per year on silty-clay or clay soils in the Philippines had greater SOC and TN concentrations in the top $20 \mathrm{~cm}$ with the application of N-K, N-P and N-P-K fertilization than in areas with no fertilization after 17 to 21 years of continuous production.

\subsection{Crop rotation effects on SOC and TN}

As hypothesized, SOC $(P<0.001)$ and TN $(P=0.003)$ contents $\left(\mathrm{kg} \mathrm{m}^{-2}\right)$ in the top $10 \mathrm{~cm}$ were affected by crop rotation and time, when averaged across tillage treatments and fertility regimes (Table 5). The SOC content in rotations that included winter wheat [i.e., $R(W)$ and

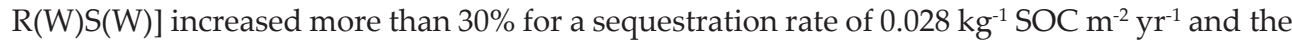
continuous rotation increased $16 \%$ for a sequestration rate of $0.014 \mathrm{~kg}^{-1} \mathrm{SOC} \mathrm{m} \mathrm{yr}^{-1}$ from 1999 to 2010, whereas SOC contents in the RS, RC, and RCS rotations did not differ over the 11-year time period (Figure 1A). Likewise, TN contents increased 36 to $46 \%$ in the $R(W)$ rotation for a sequestration rate of $0.003 \mathrm{~kg}^{-1} \mathrm{TN} \mathrm{m}^{-2} \mathrm{yr}^{-1}$ and in the $\mathrm{R}(\mathrm{W}) \mathrm{S}(\mathrm{W})$ rotation for a sequestration rate of $0.004 \mathrm{~kg}^{-1} \mathrm{TN} \mathrm{m}^{-2} \mathrm{yr}^{-1}$ (Figure 1B). However, the RS rotation increased $19 \%$ for a sequestration rate of $0.002 \mathrm{~kg}^{-1} \mathrm{TN} \mathrm{m}^{-2} \mathrm{yr}^{-1}$ from 1999 to 2010, whereas the TN contents in R, $\mathrm{RC}$, and RCS rotations did not differ over time (Figure 1B). The greater increase of SOC and 
TN over time in rotations with wheat could be partially due to greater quantities of annual biomass from the double-cropped rotations, as opposed to rotations that were fallow in the winter, and partially due to the presence of wheat in the ground during sampling. The presence of the wheat crop suggests there were greater concentrations of fresh root biomass and increased microbial activity in the near-surface soil compared to rotations that were fallow during the winter.

The increases in SOC and TN correspond to similar observed differences in SOM among rotations and increases in SOM content over time. Soil organic matter content increased $14 \%$ from $1999\left(2.58 \mathrm{~kg} \mathrm{~m}^{-2}\right)$ to $2010\left(2.95 \mathrm{~kg} \mathrm{~m}^{-2}\right)$, when averaged across all tillage, fertility and rotation treatment combinations, and SOM content was 5 to $13 \%$ greater in $R(W)\left(3.01 \mathrm{~kg} \mathrm{~m}^{-2}\right)$ than in all other crop rotations ( 2.67 to $2.78 \mathrm{~kg} \mathrm{~m}^{-2}$ ), when averaged across tillage, fertility and time (Motschenbacher et al., 2012). However, SOC contents only increased in the R(W), $R(W) S(W)$, and $R$ rotations and TN contents only increased in the $R(W), R(W) S(W)$, and RS rotations over the 11-year period, whereas SOM content changes over time were unaffected by individual crop rotations (Motschenbacher et al., 2012).

Increasing the amount of SOC, and associated TN, in the soil requires the addition of enough crop residue to exceed the losses from SOM decomposition, erosion and leaching (Follett, 2001). This can be accomplished by using crop rotation systems that can influence the volume, distribution and turnover of the active and passive pools of SOC (Franzluebbers et al., 1994). Examining each year separately and averaged across tillage and fertility regimes, SOC content in the RCS $\left(1.04 \mathrm{~kg} \mathrm{~m}^{-2}\right)$ rotation was $14 \%$ greater than that in the $\mathrm{R}(\mathrm{W}) \mathrm{S}(\mathrm{W})\left(0.91 \mathrm{~kg} \mathrm{~m}^{-2}\right)$ rotation at the beginning of the study in 1999, while SOC contents in all other rotations did not differ (Figure 1A). For TN content, there were no differences among crop rotations in 1999 (Figure 1B). However, after 11 years of continuous management, the $\mathrm{R}(\mathrm{W})\left(1.32 \mathrm{~kg} \mathrm{~m}^{-2}\right)$ and $\mathrm{R}(\mathrm{W}) \mathrm{S}(\mathrm{W})\left(1.22 \mathrm{~kg} \mathrm{~m}^{-2}\right)$ rotations had 15 to $28 \%$ greater SOC contents than rotations that included corn [i.e. RC $\left(1.03 \mathrm{~kg} \mathrm{~m}^{-2}\right)$ and RCS $\left(1.06 \mathrm{~kg} \mathrm{~m}^{-2}\right)$; Figure 1A]. Furthermore, the R(W) rotation had 15 to $28 \%$ greater SOC content in 2010 than that in the R, RS, RC, and RCS rotations (1.03 to $1.15 \mathrm{~kg} \mathrm{~m}^{-2}$ ), which did not differ between one another (Figure 1A). In 2010, TN content was 14 to $27 \%$ greater in the $R(W)\left(0.14 \mathrm{~kg} \mathrm{~m}^{-2}\right)$ and $R(W) S(W)\left(0.13 \mathrm{~kg} \mathrm{~m}^{-2}\right)$ rotations than that in any of the other crop rotations ( 0.11 to $\left.0.12 \mathrm{~kg} \mathrm{~m}^{-2}\right)$, whereas TN content among the R, RS, RC, and RCS rotations in 2010 did not differ (Figure 1B). Greater TN contents in winter-wheat rotations [i.e., $\mathrm{R}(\mathrm{W})$ and $\mathrm{R}(\mathrm{W}) \mathrm{S}(\mathrm{W})$ ] compared to the $\mathrm{R}, \mathrm{RS}, \mathrm{RC}$, and RCS rotations could partially be due to the timing of the last fertilizer-N application prior to the 2010 sampling date in mid-March. The $\mathrm{R}(\mathrm{W})$ and $\mathrm{R}(\mathrm{W}) \mathrm{S}(\mathrm{W})$ rotations received $\mathrm{N}$ fertilization at the beginning of March 2009 for the winter-wheat crop, whereas the last application of $\mathrm{N}$ fertilizer was in the previous spring (i.e., Spring 2009) for all other crop rotations (Table 2).

Dick et al. (1998) concluded that crop rotation and cover crops are an effective way to facilitate C sequestration, especially when combined with NT and optimal fertilization. After evaluating 67 long-term agricultural studies, West and Post (2002) estimated that enhancing the rotation complexity, including changing from monoculture to continuous rotation cropping, cropfallow to continuous monoculture or rotation cropping, or increasing the number of crops in a rotation system, can sequester an average of $0.02 \pm 0.01 \mathrm{~kg} \mathrm{C} \mathrm{m}^{-2} \mathrm{yr}^{-1}$ in the top $30 \mathrm{~cm}$ of 
dryland systems. However, these results excluded the change from continuous corn to cornsoybean, which may not lead to a significant change in SOC (West and Post, 2002). The rate reported in West and Post (2002) is comparable to the SOC sequestration rate of $0.03 \mathrm{~kg}^{-1} \mathrm{~m}^{-2}$ $\mathrm{yr}^{-1}$ in the top $10 \mathrm{~cm}$ for rotations which included winter wheat [i.e., $\mathrm{R}(\mathrm{W})$ and $\mathrm{R}(\mathrm{W}) \mathrm{S}(\mathrm{W})$ ] in this study compared to continuous rice $\left(0.01 \mathrm{~kg}^{-1} \mathrm{~m}^{-2} \mathrm{yr}^{-1}\right)$ and other rotations, which did not significantly sequester SOC over time.

In this study, crop rotation appeared to be a major contributor to the quantity of SOC present in the top $10 \mathrm{~cm}$. Rice and corn are two high-residue-producing crops that are capable of producing $6.5 \mathrm{Mg} \mathrm{ha}^{-1}$ (rice) to $8.0 \mathrm{Mg} \mathrm{ha}^{-1}$ (corn) of above-ground dry matter per crop produced under adequate fertilization, whereas soybean is only capable of producing around $2.2 \mathrm{Mg}$ ha $^{-1}$ of above-ground dry matter during a cropping season (USDA-NASS, 2012). The aboveground biomass quantities produced annually can also be increased by double-cropping a system with wheat (West and Post, 2002), which is capable of producing an additional $3.3 \mathrm{Mg}$ dry matter ha ${ }^{-1}$ per year (USDA-NASS, 2012), as opposed to keeping the rotation fallow for the winter. For this study, rotations that produced rice and wheat during a year [i.e., $R(W)$ and $\mathrm{R}(\mathrm{W}) \mathrm{S}(\mathrm{W})$ ] were capable of producing $9.8 \mathrm{Mg}$ dry matter ha-1 per year, and during the years soybean and wheat were grown, the $\mathrm{R}(\mathrm{W}) \mathrm{S}(\mathrm{W})$ rotation produced roughly $5.5 \mathrm{Mg}$ dry matter ha $^{-1}$ per year (USDA-NASS, 2012). Therefore, a greater SOC content in the $R(W)$ rotation after 11 years of rotation management was expected due to the consistent input of at least $23 \%$ more above-ground dry matter added annually than that from the RS, RC, and RCS rotations, and the $R(W) S(W)$ rotation during the years soybean and wheat were produced (Figure 1A).

In addition to large above-ground biomass inputs, rice is a unique crop to include in a crop rotation because unlike all other row crops, rice is grown under nearly to completely saturated soil conditions (Norman et al., 2003), which slows the rate of SOM decomposition and affects $\mathrm{N}$ cycling dynamics. Thus, flooding the soil during the period rice is produced greatly affects SOM, and consequently SOC, accumulation in the soil, which is then susceptible to rapid decomposition when the field is drained for harvest and during the fallow period. Although crop rotations involving high-residue-producing crops like corn typically facilitate substantial increases in SOC, the anaerobic conditions under which rice is grown also affect the breakdown of crop residues in the soil. Witt et al. (2000) demonstrated that soils continuously cropped with flooded rice had 11 to $12 \%$ more $\mathrm{C}$ sequestration and 5 to $12 \%$ more $\mathrm{N}$ accumulation than soils which supported a dry-season, maize-flooded-rice rotation. The results were attributed to a 33 to $41 \%$ increase in the estimated amount of mineralized-C and decreased input of $\mathrm{N}$ from biological $\mathrm{N}$ fixation during the dry-season, maize-cropping period (Witt et al., 2000). Aulakh et al. (2001) reported that C sequestration in a sandy-loam soil in India was 69 to $107 \%$ greater when wheat residues were added to flooded rice. Furthermore, Aulakh et al. (2001) also showed that adding wheat residue immobilized mineral-N during the fallow period, but the amount of mineral-N increased rapidly at the start of the flooded rice season when green manure or urea-N were applied.

The increase in TN in the RS rotation over time in this study can be explained by the increased frequency of an $\mathrm{N}$-fixing legume crop in the rotation, whereas the R, RC, and RCS did not result in increased TN over time (Figure 1B). This is because the Rhizobia bacteria present in 
the nodules on legume roots are able to absorb dinitrogen gas $\left(\mathrm{N}_{2}\right)$ from the air and convert it to $\mathrm{NH}_{4}{ }^{+}$, which can either be released into the soil or taken up by the plant and returned to the soil as residue-N at a later time (Havlin et al., 2005). The $\mathrm{R}(\mathrm{W}) \mathrm{S}(\mathrm{W})$ rotation also had a biennial rotation with soybean, but it is unclear whether the increase in TN content over time was a result of having a leguminous crop present in the rotation or related to the application of fertilizer-N in the fall. The $\mathrm{R}(\mathrm{W}) \mathrm{S}(\mathrm{W})$ rotation had a similar TN content as the $\mathrm{R}(\mathrm{W})$ rotation in 2010, which also had fertilizer-N applied in the fall, but did not include a leguminous crop (Figure 1B). These results are similar to those of Granatstein et al. (1987) from a 10-year study of winter wheat-legume rotations using different tillage regimes. They reported the greatest increase in $\mathrm{TN}$ in the top $5 \mathrm{~cm}$ was in rotations with greater frequencies of $\mathrm{N}$-fixing legume crops in the rotation.

\subsection{Partitioning of SOC and TN within SOM}

Similar to SOC and TN contents, the fraction of SOM made up by SOC in the top $10 \mathrm{~cm}$ differed between tillage treatments $(P=0.007)$, when averaged across fertility, rotation and time. Also similar to SOC and TN contents, the fraction of SOM made up by SOC $(P=0.047)$ and TN $(P$ $=0.037)$ differed by rotation and time, when averaged across tillage and fertility regimes, but SOC and TN fractions of SOM were unaffected by fertility regime $(P>0.05$; Table 5).

The fraction of SOM made up of SOC was $5 \%$ greater under NT $(39.7 \%)$ than that under CT $(37.7 \%)$. Furthermore, the fraction of SOM made up of SOC was roughly $1.4 \%$ greater in the RS rotation in $1999(40.7 \%)$ and $R(W) S(W)$ rotation in 2010 (40.4\%) than the $R(W) S(W)$ rotation in 1999 (35.6\%), whereas there were no differences in the SOC fraction of SOM among any other rotation-time combinations. Therefore, the fraction of SOM made up of SOC increased $13 \%$ over 11 years in the $\mathrm{R}(\mathrm{W}) \mathrm{S}(\mathrm{W})$ rotation, but the SOC fraction of SOM did not change over time in any other rotation evaluated. The fraction of SOM made up of TN was $2 \%$ greater in the $R(W) S(W)$ rotation in 2010 (4.4\%) than in the $R, R C, R(W), R(W) S(W)$, and RCS rotations in 1999 and the $\mathrm{R}$ and $\mathrm{RC}$ rotations in 2010 (both years ranged from 3.7 to 3.9\%). Similar to SOC, the TN fraction of SOM in the R(W)S(W) increased 21\% from 1999 (3.6\%) to 2010 (4.4\%).

Although there were differences in the SOC and TN fractions of SOM, these differences only ranged from 1 to $5 \%$. With the exception of the RS rotation in 1999, which had a greater fraction of SOC in SOM, only the R(W)S(W)/2010 treatment combination had greater SOC and TN fractions of $S O M$ than a majority of the other rotation-time combinations. Furthermore, the R, $R C, R(W), R(W) S(W)$, and RCS rotations in 1999 and the R, RS, RC, R(W), and RCS rotations in 2010 did not differ in their SOC and TN fractions of SOM. Therefore, there is a possibility that the greater SOC and TN fractions of SOM in R(W)S(W) in 2010 could be an isolated sampling discrepancy instead of a true rotation effect over time.

\subsection{Soil C:N ratio}

The soil C: $\mathrm{N}$ ratio in the top $10 \mathrm{~cm}$ was unaffected by tillage, fertility, rotation or time $(P>0.05$; Table 5). Carbon:N ratios ranged from 8.1 to 14.0 in both 1999 and 2010. The C:N ratio of the soil is important because $\mathrm{N}$ is essential to microbial growth and reproduction, thus the 
microorganisms must obtain $\mathrm{N}$ either from the material being decomposed or an external source (i.e., inorganic $\mathrm{N}$ fertilizer compounds in the soil) in order to continue consuming SOM (Wolf and Snyder, 2003). If the SOM being decomposed has a large C:N ratio, then soil microbes either have to acquire $\mathrm{N}$ from the surrounding soil or decrease the rate of decomposition (Havlin, 2005). A common rule of thumb is that a C:N ratio of 20 to 30 in crop residues maintains an equilibrium mineral-N level in the soil, whereas any $\mathrm{C}: \mathrm{N}$ ratio above 30 results in a net loss of $\mathrm{NH}_{4}{ }^{+}$and $\mathrm{NO}_{3}^{-}-\mathrm{N}$, and a $\mathrm{C}: \mathrm{N}$ ratio below 20 results in a net gain of $\mathrm{NH}_{4}{ }^{+}$and $\mathrm{NO}_{3}{ }^{-} \mathrm{N}$ (Stevenson and Cole, 1999). However, in this study there were no differences in soil C:N ratios among treatment combinations evaluated.

\subsection{Century model SOC and TN contents}

The linear relationship between Century-modeled and measured SOC $(P=0.010)$ and soil TN $(P=0.024)$ after 11 years of consistent management was significant, but there were relatively weak predictive relationships between modeled and measured SOC $\left(\mathrm{r}^{2}=0.14\right.$; Figure 3A) and TN ( $\mathrm{r}^{2}=0.10$; Figure $\left.3 \mathrm{~B}\right)$ contents. For the analyses of SOC and soil TN contents, all modeled estimations for the 24 tillage-fertility-rotation treatment combinations were evaluated against the means of direct observation from 2010. The mean values of the direct observations were used to get a direct comparison between modeled and measured SOC and soil TN contents.

\begin{tabular}{|c|c|c|c|c|c|c|c|c|c|c|c|c|c|c|c|c|}
\hline \multirow[b]{4}{*}{ Rotation } & \multicolumn{8}{|c|}{$\operatorname{SOC}\left(\mathrm{kg} \mathrm{m}^{-2}\right)$} & \multicolumn{8}{|c|}{$\mathrm{TN}\left(\mathrm{kg} \mathrm{m}^{-2}\right)$} \\
\hline & \multicolumn{4}{|c|}{ Measured } & \multicolumn{4}{|c|}{ Modeled } & \multicolumn{4}{|c|}{ Measured } & \multicolumn{4}{|c|}{ Modeled } \\
\hline & \multicolumn{2}{|c|}{ СT } & \multicolumn{2}{|c|}{ NT } & \multicolumn{2}{|c|}{ CT } & \multicolumn{2}{|c|}{ NT } & \multicolumn{2}{|c|}{ СT } & \multicolumn{2}{|c|}{ NT } & \multicolumn{2}{|c|}{ СT } & \multicolumn{2}{|c|}{ NT } \\
\hline & 0 & so & 0 & so & 0 & so & 0 & so & 0 & so & 0 & so & 0 & so & 0 & so \\
\hline $\mathrm{R}$ & 1.11 & 0.97 & 1.28 & 1.22 & 1.72 & 1.67 & 1.95 & 1.67 & 0.12 & 0.12 & 0.11 & 0.09 & 0.15 & 0.13 & 0.17 & 0.14 \\
\hline RS & 0.96 & 0.93 & 1.24 & 1.26 & 1.42 & 1.38 & 1.38 & 1.34 & 0.14 & 0.13 & 0.10 & 0.10 & 0.12 & 0.11 & 0.12 & 0.11 \\
\hline RC & 0.84 & 0.90 & 1.19 & 1.18 & 1.94 & 1.86 & 1.95 & 1.84 & 0.13 & 0.12 & 0.09 & 0.10 & 0.17 & 0.15 & 0.17 & 0.15 \\
\hline$R(W)$ & 1.20 & 1.21 & 1.45 & 1.43 & 1.38 & 1.38 & 1.43 & 1.42 & 0.15 & 0.15 & 0.13 & 0.12 & 0.12 & 0.12 & 0.13 & 0.12 \\
\hline $\mathrm{R}(\mathrm{W}) \mathrm{S}(\mathrm{W})$ & 1.08 & 1.08 & 1.49 & 1.22 & 1.46 & 1.41 & 1.37 & 1.37 & 0.17 & 0.13 & 0.12 & 0.12 & 0.13 & 0.13 & 0.13 & 0.12 \\
\hline RCS & 1.01 & 1.06 & 1.10 & 1.07 & 1.74 & 1.66 & 1.72 & 1.62 & 0.12 & 0.12 & 0.11 & 0.10 & 0.15 & 0.13 & 0.15 & 0.13 \\
\hline
\end{tabular}

Table 6. Measured and Century-estimated soil organic carbon (SOC) and total nitrogen (TN) contents under different tillage [conventional tillage (CT) and no-tillage (NT)], fertility [optimal (O) and sub-optimal (SO)] and crop rotation [with soybean (S), corn (C), and/or wheat (W)] treatment combinations after an 11-yr study period (1999 to 2010). The study site was located at the Rice Research and Extension Center near Stuttgart, AR on a silt-loam soil. Values presented are the measured and model predictions from the 2010 sampling period. Crops in parentheses were grown during the winter.

A numerical evaluation of Century-estimated values and direct observations over the 11-year study period (1999 to 2010) indicated that the Century model estimated greater SOC (Figure 4A) and TN (Figure 4B) contents than that measured in 2010 (Table 6). Century-modeled SOC 

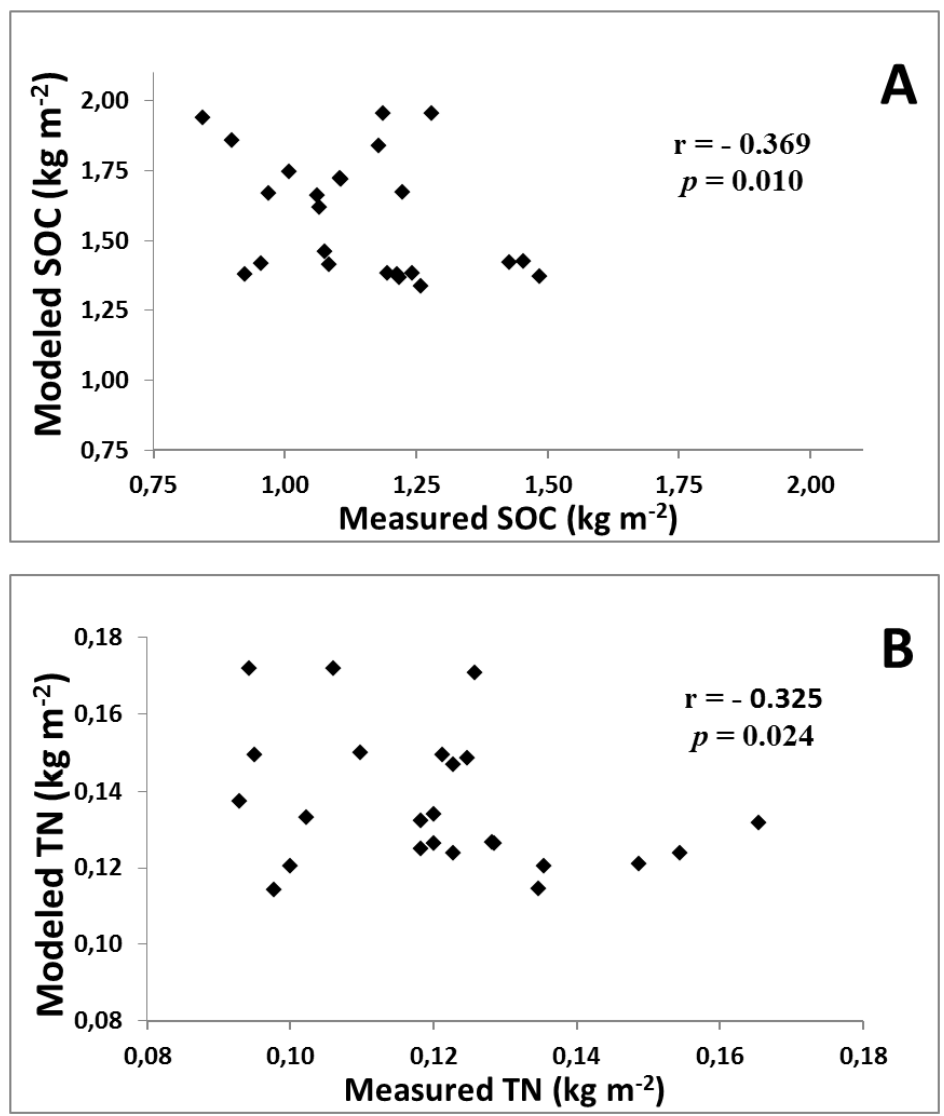

Figure 3. Century-modeled verses measured soil organic carbon (SOC) $[\mathrm{A}]$ and total nitrogen (TN) [B] contents in the top $10 \mathrm{~cm}$ after 11 years of management for 24 different tillage-fertility-rotation treatment combinations.

contents were numerically greater than measured SOC contents by $6 \%\left(0.08 \mathrm{~kg} \mathrm{SOC} \mathrm{m}^{-2}\right)$ to $56 \%\left(1.10 \mathrm{~kg} \mathrm{SOC} \mathrm{m}^{-2}\right)$ in all tillage-fertility-rotation treatment combinations except for the NT/ optimal/R(W), NT/sub-optimal/R(W), and the NT/optimal/R(W)S(W) treatment combinations,

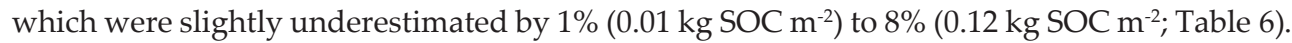

On average, Century-modeled SOC contents overestimated SOC by $26 \%$. Estimated SOC in 8 of the 24 treatment combinations differed less than $14 \%$ from directly measured SOC in 2010, while the other 16 treatment combinations exceeded a $23 \%$ difference from measured SOC (Table 6). It appears that this overestimation by Century would increase into the future if management practices continued into the future (Figure 3A). The overestimation of SOC during a longer time period in this study is similar to modeling results reported by Bhattacharyya et al. (2007) in a jute (Cochorus capsularis L.)-rice-wheat rotation over a 30-year period. Bhattacharyya et al. (2007) reported that SOC was generally overestimated by $15 \%$ in the top 

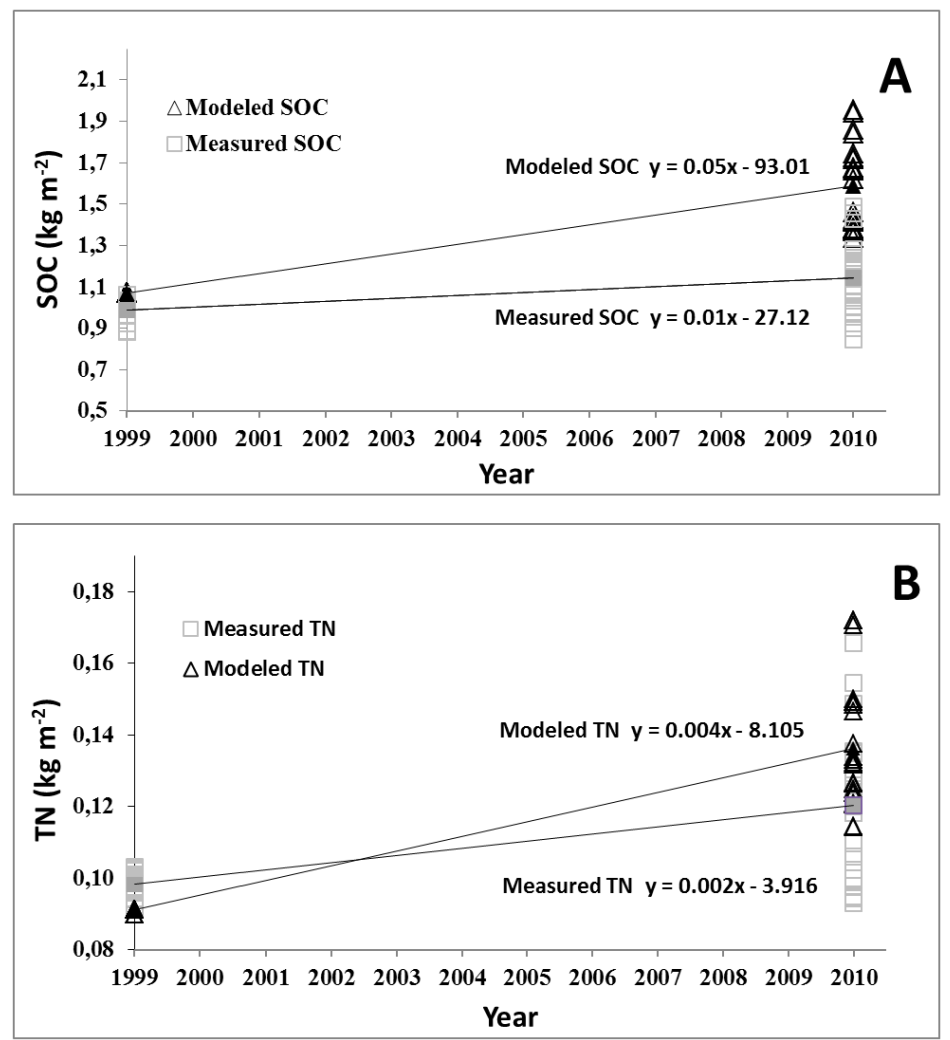

Figure 4. Century-modeled and measured soil organic carbon (SOC) $[\mathrm{A}]$ and total nitrogen (TN) $[\mathrm{B}]$ contents in the top $10 \mathrm{~cm}$ over time (1999 and 2010) for 24 different tillage-fertility-rotation treatment combinations. The regression equations on each graph represent the average modeled and measured SOC and TN contents across all treatment combinations over time.

$20 \mathrm{~cm}$ when modeled in Century. Therefore, if the model were to be used for more accurate prediction in the rice-based rotations, such as those used in this study, a more in-depth evaluation and further adjustments of the Century modeling environment for flood-irrigation would be necessary.

Similar to modeled SOC, Century-modeled soil TN contents were also generally greater than the direct measurements after 11 years of management. Soil TN was greater by $1 \%(1.0 \mathrm{~g}$ SOC $\left.\mathrm{m}^{-2}\right)$ to $45 \%\left(78 \mathrm{~g} \mathrm{SOC}^{-2}\right)$ in most treatment combinations except in the NT/optimal/R(W), CT/optimal/RS, CT/optimal/R(W), CT/optimal/R(W)S(W), CT/sub-optimal/RS, CT/suboptimal/R(W), and CT/sub-optimal/R(W)S(W), which were underestimated by $1 \%(<0.01 \mathrm{~kg}$ $\left.\mathrm{TN} \mathrm{m}^{-2}\right)$ to $26 \%\left(0.03 \mathrm{~kg} \mathrm{TN} \mathrm{m}^{-2}\right.$; Table 6$)$. On average, the modeled soil TN content was overestimated by $10 \%$ across all tillage-fertility-rotation treatment combinations, which was a more accurate value than that of the average estimated SOC content over time. Centurymodeled soil TN in 14 of the 24 treatment combinations had a range of less than $19 \%$ different 
from measured observations, whereas the other 10 treatment combinations exceeded a $23 \%$ difference from measured observations (Table 6). Similar to the pattern of modeled SOC, it appears that this overestimation of soil TN by Century would also continue to increase slightly over time if management practices continued into the future (Figure 3B).

Based on numeric values for modeled estimations and direct observations, it appears that Century can predict SOC and TN contents more accurately for certain tillage-fertility-rotation treatment combinations compared to other modeled treatment combinations (Table 6). The closest estimations of SOC to direct observations were for treatment combinations that included rotations with winter wheat [i.e., $R(W)$ and $R(W) S(W)$ ] during the study period, and the closest estimations for soil TN over time occurred in treatment combinations that included the $\mathrm{R}(\mathrm{W}) \mathrm{S}(\mathrm{W})$ rotation (Table 6). The least accurate estimations of SOC compared to direct observations were for treatment combinations that included rotations with corn (i.e., RC and RCS), and the closest estimations for soil TN were in treatment combinations that included the $\mathrm{R}(\mathrm{W})$ rotation (Table 6). The predicted estimates of SOC and soil TN contents for rotations that included wheat could be a result of overestimating or underestimating the inputs from the winter wheat crop, which was in the ground during the time of soil sampling. The overestimation of SOC contents for rotations with corn could be a result of reduced yields at the study site compared to common yield values produced in the local geographic area, which is the yield value simulated in the Century model. This could be a result of many factors, but the more likely scenario is that the size of the research plot resulted in essentially an edge effect that would not be present in larger production fields.

The inaccuracies associated with the modeling results suggest that a few input parameters could be better adjusted in the Century model to more accurately predict SOC and TN cycling in rice-based crop rotations that are flooded for a majority of the growing season. Perhaps incorporation of the measured plant nutrient composition of the specific crop varieties grown during the study period and specific yields in each research area sampled over the 11-year period would improve the accuracy of specific input variables. Furthermore, soil sampling to a greater soil depth for more direct comparison to Century-modeled results might create not only a greater understanding of soil cycling in the near-surface soil, but also could help improve the overall accuracy of the model.

\section{Summary and conclusions}

This study demonstrated SOC and soil TN contents in the top $10 \mathrm{~cm}$ were affected by tillage, rotation and/or time after 11 years of consistent management. As hypothesized, soil TN contents increased over time under NT, but SOC contents did not differ under either tillage treatment (i.e., NT and CT) over the 11-year study period. Furthermore, soil under high-residue-producing rotations double-cropped with winter wheat [i.e. $R(W)$ and $R(W) S(W)$ ] had greater increases in both SOC and TN contents over time compared to all other crop rotations. The only highresidue-producing, mono-cropped rotation with greater SOC over time was continuous rice, whereas SOC contents in all other crop rotations (i.e., RS, RC, and RCS) did not differ during 
the 11-year study period. Similar to the double-cropped rotations, the RS rotation also had an increase of soil TN over time. However, other crop rotations (i.e., R, RC, and RCS) did not differ in soil TN contents over time. In contrast to that hypothesized, fertility treatments had no effect on SOC and TN contents. The primary difference in SOC and TN contents among treatment combinations included the presence or absence of a winter wheat crop.

The Century model is a predictive tool for future environmental nutrient cycling estimations. Results from this study suggest that Century can be used to predict general trends in SOC and $\mathrm{TN}$ cycling in rice-based crop rotations over time, but further adjustment of the model is needed to increase accuracy. The direct measurements and the modeled estimations from this study are important because there has not been a great amount of research conducted on SOC and TN storage in dry-seeded, delayed-flooded rice production systems. A majority of $\mathrm{C}$ and $\mathrm{N}$ research in agricultural systems has either been conducted on non-flooded crops or in paddy-grown rice. Relatively few studies have actually evaluated long-term SOC and TN storage using dryseeded, delayed-flood rice production practices commonly used in the Unites States.

This study was meant to provide a long-term evaluation of SOC and TN storage in soil used for flood-irrigated, rice-based crop rotations. Because soil moisture conditions have such a large impact on the overall storage of SOC and the cycling of N in the soil, examining crop production systems that contain periods of both aerobic and anaerobic conditions is an important component in obtaining a more accurate global estimate of SOC and TN storage in agricultural production systems. The results obtained from this study can help contribute to the ongoing effort to study the sustainability of rice cropping in the United States by enabling the direct quantification of $\mathrm{C}$ and $\mathrm{N}$ storage in the soil over time.

\section{Acknowledgements}

This study was partially funded by the Arkansas Rice Research and Promotion Board. Field assistance provided by Terry Sells, Daniel McCarty and Tara Moss Clayton is gratefully acknowledged.

\section{Author details}

Jill M. Motschenbacher ${ }^{1 *}$, Kristofor R. Brye ${ }^{1}$, Merle M. Anders ${ }^{1}$, Edward E. Gbur ${ }^{2}$, Nathan A. Slaton ${ }^{1}$ and Michelle A. Evans-White ${ }^{3}$

*Address all correspondence to: jmotsche@email.uark.edu

1 Department of Crop, Soil and Environmental Sciences, University of Arkansas, USA

2 Agricultural Statistics Laboratory, University of Arkansas, USA

3 Department of Biological Sciences, University of Arkansas, USA 


\section{References}

[1] Alvarez, R., and R.S. Lavado. 1998. Climate, organic matter and clay content relationship in the Pampa and Chaco soils, Argentina. Geoderma 83:127-141.

[2] Angers, D.A., and N.S. Eriksen-Hamel. 2008. Full-inversion tillage and organic carbon distribution: A meta-analysis. Soil Sci. Soc. J. Am. 72:1370-1374.

[3] Ashlock, L. 2000. Arkansas soybean handbook. Handbook. MP 197. Univ. of Arkansas Coop. Ext. Serv., Little Rock.

[4] Aulakh, M.S., T.S. Khera, J.W. Doran, and K.F. Bronson. 2001. Managing crop residue with green manure, urea, and tillage in a rice-wheat rotation. Soil Sci. Soc. Am. J. 65:820-827.

[5] Bhattacharyya, T., D.K. Pal, M. Easter, S. Williams, K. Paustian, E. Milne, P. Chandran, S.K. Ray, C. Mandal, K. Coleman, P. Falloon, D.S. Powlson, and K.S. Gajbhiye. 2007. Evaluating the Century model using long-term fertiliser trials in the IndoGangetic Plains, India. In: E. Milne, D.S. Powlson, and C.E.P. Cerri (eds.) Soil carbon stocks at regional scales. Agric. Ecosys. Environ. 122:73-83.

[6] Bayer, C. 1996. Dinâmica da material organic em sistemas de manejo de solos. (In Portuguese.) Tese de Doutorado em Ciênia do Solo, PPG-Agronomia, UFRGS, Porto Alegre. As cited in C. Bayer, L. Martin-Neto, J. Mielniczuk, C.N. Pillon, and L. Sangoi. 2001. Changes in soil organic matter fractions under subtropical no-till cropping systems. Soil Sci. Soc. Am. J. 65:1473-1478.

[7] Bot, A., and J. Benites. 2005. The importance of soil organic matter. Food and Agriculture Organization of the United Nations, Rome. [online] Available at http:// www.fao.org/docrep/009/a0100e/a0100e00.htm (verified 22 July, 2012).

[8] Brye, K.R., M.L. Cordell, D.E. Longer, and E.E. Gbur. 2006a. Residue management practice effects on soil surface properties in a young wheat-soybean double-cropping system. J. Sustain. Agric. 29:121-150.

[9] Brye, K.R., D.E. Longer, and E.E. Gbur. 2006b. Impact of tillage and residue burning on $\mathrm{CO}_{2}$ flux in a wheat-soybean production system. Soil Sci. Soc. Am. J. 70:1145-1154.

[10] Brye, K.R., N.A. Slaton, M.C. Savin, R.J. Norman, and D.M. Miller. 2003. Short-term effects of land leveling on soil physical properties and microbial biomass. Soil Sci. Soc. Am. J. 67:1405-1417.

[11] Chang, T. 2003. Origin, domestication, and diversification. pp. 3-26. In C.W. Smith and R.H. Dilday. (eds.) Rice: Origin, history, technology, and production. John Wiley \& Sons, Inc., NJ. 
[12] Clapp, C.E., R.R. Allmaras, M.F. Layese, D.R. Linden, and R.H. Dowdy. 2000. Soil organic Carbon and ${ }^{13} \mathrm{C}$ abundance as related to tillage, crop residue, and nitrogen fertilization under continuous corn management in Minnesota. Soil Till. Res. 55:127-142.

[13] DeBusk, W.F., J.R. White, and K.R. Reddy. 2001. Carbon and nitrogen dynamics in wetland soils. pp. 27-53. In M. J. Shaffer, L. Ma, and S. Hansen. (eds.) Modeling carbon and nitrogen dynamics for soil management. CRC Press, Boca Raton, FL.

[14] De Datta, S.K. 1981. Principles and practices of rice production. International Rice Research Institute. John Wiley \& Sons, Inc., Singapore. [online] Available at http:// books.irri.org/0471097608_content.pdf (verified 21 July, 2012).

[15] Denman, K.L., G. Brasseur, A. Chidthaisong, P. Ciasis, P.M. Cox, R.E. Dickinson, D. Hauglustaine, C. Heinze, E. Holland, D. Jacob, U. Lohmann, S. Ramachandran, P.L. da ilva Dias, S.C. Wofsy, and X. Zhang. 2007. Couplings between changes in the climate system and biogeochemistry. In: S. Solomon, D. Qin, M. Manning, Z. Chen, M. Marquis, K. B. Averyt, M. Tignor, and H.L. Miller. (eds.) Climate Change 2007: The Physical Science Basis. Contribution of working group I to the fourth assessment report of the Intergovernmental Panel on Climate Change. Cambridge University Press, Cambridge, United Kingdom and New York, NY, USA.

[16] Dick, W.A., R.L. Blevins, W.W. Frye, S.E. Peters, D.R. Christenson, F.J. Pierce, and M.L. Vitosh. 1998. Impacts of agricultural management practices on C sequestration in forest-derived soils of the eastern Corn Belt. Soil Till. Res. 47:235-244.

[17] Espinoza, L., and J. Ross. 2003. Corn production handbook. Handbook. MP 437. Univ. of Arkansas Coop. Ext. Serv., Little Rock.

[18] Espinoza, L., N. Slaton., and M. Mozaffari. 2007. Understanding the numbers on your soil test report. University of Arkansas Extension Publication FSA 2118 [online]. Available at http://www.uaex.edu/Other_Areas/publications/pdf/FSA-2118.pdf (verified 6 July, 2012).

[19] Farquhar, G.D., M.J.R. Fasham, M.L. Goulden, M. Heimann, V.J. Jaramillo, H.S. Kheshgi, C. Le Quéré, R.J. Scholes, and D.W.R. Wallace. 2001. The carbon cycle and atmospheric carbon dioxide. In J.T. Houghton, Y. Ding, D.J. Griggs, M. Noguer, P.J. van der Linden, X. Dai, K. Maskell, and C.A. Johnston. (eds.) Climate change 2001: The scientific basis. IPCC, Wembley, United Kingdom.

[20] Filcheva, E., and T. Mitova. 2002. Effect of crop rotation and the composition of soil organic matter. pp. 237-263. In J.M. Kimble, R. Lal, and R.F. Follett. (eds.) Agricultural practices and policies for carbon sequestration in soil. CRC Press, Boca Raton, FL.

[21] Follett, R.F. 2001. Soil management concepts and carbon sequestration in cropland soils. Soil Till. Res. 61:77-92. 
[22] Granatstein, D.M., D.F. Bezdicek, V.L. Cochran, L.F. Elliott, and J. Hammel. 1987. Long-term tillage and rotation effects on soil microbial biomass, carbon and nitrogen. Bio. Fert. Soils 5:265-270.

[23] Halvorson, A.D., B.J. Wienhold, and A.L. Black. 2002. Tillage, nitrogen, and cropping system effects on soil carbon sequestration. Soil Sci. Soc. Am. J. 66:906-912.

[24] Havlin, J.L., J.D. Beaton, S.L. Tisdale, and W.L. Nelson. 2005. Soil fertility and fertilizers: An introduction to nutrient management $7^{\text {th }}$ ed. Pearson Education, Inc. Upper Saddle River, NJ.

[25] Intergovernmental Panel on Climate Change (IPCC). 2007. Climate change 2007: Synthesis report [online]. Core Writing Team, R.K. Pachauri, and A. Reisinger (eds.) Available at http:www.ipcc.ch/pdf/assessment-report/ar4/syr/ar4_syr.pdf (verified 23 July, 2012).

[26] Kelley, J. 1999. Arkansas wheat production and management. Handbook. MP 404. Univ. of Arkansas Coop. Ext. Serv., Little Rock.

[27] Kern, J.S., and M.G. Johnson. 1993. Conservation tillage impacts on national soil and atmospheric carbon levels. Soil Sci. Soc. Am. J. 57:200-210.

[28] Lal, R. 2004. Soil carbon sequestration impacts on global climate change and food security. Science 304:1623-1627.

[29] Lal, R. 2007. Soil Physical Properties and Erosion. pp. 165-178. In J.M. Kimble, C.W. Rice, D. Reed, S. Mooney, R.F. Follett, and R. Lal. (eds.) Soil carbon management: Economic, environmental and societal benefits. CRC Press, Boca Raton, FL.

[30] Lal, R., and J.M. Kimble. 1997. Conservation tillage for carbon sequestration. Nutr. Cycl. Agroecosyst. 49:243-253.

[31] Lal, R., J. Kimble, R.F. Follett, and C.V. Cole. 1998. The potential of US cropland to sequester carbon and mitigate the greenhouse effect. p. 128. Ann Arbor Press, Chelsea MI.

[32] Majumder, B., B. Mandal, P.K. Bandyopadhyay, and J. Chaudhury. 2007. Soil organic carbon pools and productivity relationships for a 34 year old rice-wheat-jute agroecosystem under different fertilizer treatments. Plant Soil 297:53-67.

[33] McCarty, G.W., N.N. Lyssenko, and J.L. Starr. 1998. Short-term changes in soil carbon and nitrogen pools during tillage management transition. Soil Sci. Soc. Am. J. 62:1564-1571.

[34] McGill, W.B., and C.V. Cole. 1981. Comparative aspects of cycling of organic C, N, S, and $\mathrm{P}$ through soil organic matter. Geoderma 26:267-286.

[35] Milne, E., S. Williams, K.R. Brye, M. Ester, K. Killian, and K. Paustian. 2008. Simulating soil organic carbon in a rice-soybean-wheat-soybean chronosequence in Prairie County, Arkansas using the Century model. J. Integ. Biosciences 6:41-52. 
[36] Montgomery, D.R., D. Zabowski, F.C. Ugolini, R.O. Hallberg, and H. Spaltenstein. 2000. Soils, watershed processes, and marine sediments. pp. 159-194. In M.C. Jacobson, R.J. Charlson, H. Rodhe, and G.H. Orians. (eds.) Earth system science: From biogeochemical cycles to global change. Academic Press, San Diego, CA.

[37] Motschenbacher, J.M., K.R. Brye, M.M Anders, and E.E. Gbur. Long-term rice rotation, tillage, and fertility effects on chemical properties in a silt-loam soil. Ph.D. Diss. Chapter 4. University of Arkansas. Fayetteville, AR.

[38] National Resource Ecology Laboratory (NREL). 2006. Century soil organic matter model version 5 [online]. Available at http://www.nrel.colostate.edu/projects/century5/ (verified 23 July, 2012).

[39] Norman, R.J., C.E. Wilson, Jr., and N.A. Slaton. 2003. Soil fertilization and mineral nutrition in U.S. mechanized rice culture. pp. 331-411. In C.W. Smith and R.H. Dilday. (eds.) Rice: Origin, history, technology, and production. John Wiley \& Sons, Inc., NJ.

[40] Pampolino, M.F., E.V. Laureles, H.C. Gines, and R.J. Buresh. 2008. Soil carbon and nitrogen changes in long-term continuous lowland rice cropping. Soil Sci. Soc. Am. J. 72:798-807.

[41] Parton, W.J., and P.E. Rasmussen. 1994. Long-term effects of crop management in wheat-fallow: II. Century model simulations. Soil Sci. Soc. Am. J. 58:530-536.

[42] Parton, W.J., D.S. Schimel, C.V. Cole, and D.S. Ojima. 1987. Analysis of factors controlling soil organic levels of grasslands in the Great Plains. Soil Sci. Soc. Am. J. 51:1173-1179.

[43] Parton, W.J., J.W.B. Stewart, and C.V. Cole. 1988. Dynamics of C, N, P, and S in grassland soils: A model. Biogeochem. 5:109-131.

[44] Paustain, K., G.P. Robertson, and E.T. Elliot. 1995. Management impacts on carbon storage and gas fluxes $\left(\mathrm{CO}_{2}, \mathrm{CH}_{4}\right)$ in mid-latitudes cropland. pp. 69-83. In R. Lal, J. Kimble, E. Levine, and B.A. Stewart. (eds.) Soil management and the greenhouse effect. Lewis Publ., Boca Raton, FL.

[45] Reicosky, D.C., W.D. Kemper, G.W. Langdale, C.L. Douglas Jr., and P.E. Rasmussen. 1995. Soil organic matter changes resulting from tillage and biomass production. J. Soil Water Conserv. 50:253-261.

[46] Reicosky, D.C., and M.J. Lindstrom. 1993. Fall tillage method: Effect on short-term carbon dioxide flux from soil. Agron. J. 85:1237-1234.

[47] Salinas-Garcia, J.R., F.M. Hons, and J.E. Matocha. 1997. Long-term effects of tillage and fertilization on soil organic matter dynamics. Soil Sci. Soc. Am. J. 61:152-159.

[48] Saxton, K.E., and W.J. Rawls. 2006. Soil water characteristic estimates by texture and organic matter for hydrologic solutions. Soil Sci. Soc. Am. J. 70:1569-1578. 
[49] Schlesinger, W.H. 1997. Biogeochemistry: An analysis of global change, $2^{\text {nd }}$ ed. Academic Press, San Diego, CA.

[50] Seiter, S., and W.R. Horwath. 2004. Strategies for managing soil organic matter to supply plant nutrients. pp. 269-293. In F. Magdoff and R. R. Weil. (eds.) Soil organic matter in sustainable agriculture. CRC Press, Boca Raton, FL.

[51] Shaffer, M.J., and L. Ma. 2001. Carbon and nitrogen dynamics in upland soils. pp. 11-26. In M.J. Shaffer, L. Ma, and S. Hansen. (eds.) Modeling carbon and nitrogen dynamics for soil management. CRC Press, Boca Raton, FL.

[52] Shen, M.X., L.Z. Yang, Y.M. Yao, D.D. Wu., J. Wang, R. Guo, and S. Yin. 2007. Longterm effects of fertilizer management on crop yields and organic carbon storage of a typical rice-wheat agroecosystem of China. Biol. Fertil. Soils 44:187-200.

[53] Shibu, M.E., P.A. Leffelaar, H. Van Keulen, and P.K. Aggarwal. 2006. Quantitative description of soil organic matter dynamics: A review of approaches with reference to rice-based cropping systems. Geoderm 137:1-18.

[54] Slaton, N.A. 2001. Rice production handbook. Handbook. MP 192. Univ. of Arkansas Coop. Ext. Serv., Little Rock.

[55] Smith, J.L., R.I. Papendick, D.F. Bezdicek, and J.M. Lynch. 1993. Soil organic dynamics and crop residue management. pp. 65-94. In F.B. Metting, Jr. (ed.) Soil microbial ecology. Marcel Dekker, Inc., New York.

[56] Southern Region Climate Center (SRCC). 2012. Louisiana State University. Baton Rouge, LA. [online]. Available at http://www.srcc.lsu.edu/stations/index.php?action=metadata\&network_station_id=030240 (verified 23 July, 2012).

[57] Stevenson, F.J., and M.A. Cole. 1999. Cycles of soil. John Wiley \& Sons, Inc., New York, NY.

[58] Sundermeiser, A., R. Reeder, and R. Lal. 2005. Soil carbon sequestration - fundamentals. Ohio State University Extension Factsheet [online]. http://ohioline.osu.edu/aexfact/0510.html (verified 23 July, 2012).

[59] United States Army Corps of Engineers (USACE). 2000. Grand prairie area demonstration project: Overview [online]. Available at http://www.mvm.usace.army.mil/ grandprairie/overview/default.asp (verified 23 July, 2012).

[60] United States Department of Agriculture (USDA) Foreign Agricultural Service. (FAS). 2012. Production, supply and distribution [online]. Available at http:// www.fas.usda.gov/psdonline/psdHome.aspx (verified 16 July, 2012).

[61] United States Department of Agriculture (USDA) National Agricultural Statistics Service (NASS). 2012. Crop Explorer: United States 2011 - area, yield, and production [online]. Available at http://www.nass.usda.gov/QuickStats/PullData_US.jsp (verified 15 July, 2012). 
[62] United States Department of Agriculture (USDA) National Resources Conservation Service (NRCS). 2008. Web soil survey. Data from survey on November 12, 2008 [online]. Available at http://websoilsurvey.nrcs.usda.gov/app/WebSoilSUrvey.aspx (verified 23 July, 2012).

[63] Weil, R.R., and F. Magdoff. 2004. Significance of soil organic matter to soil quality and health. pp. 1-43. In F. Magdoff and R. R. Weil. (ed.) Soil organic matter in sustainable agriculture. CRC Press, Boca Raton, FL.

[64] West, T.O., and W.M. Post. 2002. Soil organic carbon sequestration rates by tillage and crop rotation: A global data analysis. Soil Sci. Soc. Am. J. 66:1930-1976.

[65] Witt, C., K.G. Cassman, D.C. Olk, U. Biker, S.P. Liboon, M.I. Samson, and J.C.G. Ottow. 2000. Crop rotation and residue management effects on carbon sequestration, nitrogen cycling, and productivity or irrigated rice systems. Plant Soil 225:265-278.

[66] Wolf, B., and G.H. Snyder. 2003. Sustainable soils: The place of organic matter in sustainable soils and their productivity. Food Products Press, New York.

[67] Xu, Y., W. Chen, and Q. Shen. 2007. Soil organic carbon and nitrogen pools impacted by long-term tillage and fertilization practices. Comm. Soil Sci. Plant Anal. 38:347-357. 